\title{
Development of an energy drink using soybean (Glycine max) and quinoa (Chenopodium quinoa Willd)
}

\author{
Y.A. Marrugo-Ligardo ${ }^{1 \&}$, C.A. Severiche-Sierra ${ }^{2 \&}$, J. Jaimes-Morales $^{3 \&}$, \\ W. Fong-Silva ${ }^{4 \#}$, L.E. Vargas-Ortiz ${ }^{5 \&}$

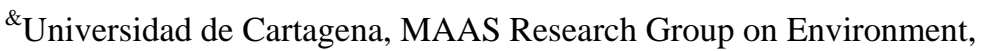 \\ Food and Health. Cartagena de indias, Bolívar, Colombia. \\ 1ymarrugol@unicartagena.edu.co, ${ }^{2}$ cseveriches@gmail.com \\ 3jjaimesm@unicartagena.edu.co, ${ }^{5}$ lvargasor@hotmail.com \\ \#Universidad de Cartagena, GIMIFEC Research Group. Cartagena de indias, Bolívar, Colombia. \\ ${ }^{4}$ wfongs@unicartagena.edu.co
}

\begin{abstract}
In this research a protein nutritional supplement was obtained, using soybean (Glycine max) and quinoa (Chenopodium quinoa Willd). Initially a flour which was mixed in different soybean / quinoa and adding water to obtain searching a protein coagulum, this was lyophilized preparing various formulations of a drink ratios was obtained, and subjected to a sensory analysis to determine the characteristics in flavor, color, aroma, body and sweetness. The content of vitamin B6 was adjusted by adding to the commercial tablets of vitamin $\mathrm{B} 6$ drink, the mixture was lyophilized again and relevant evidence to protein content, and microbiological profile of essential amino acids were performed. A protein nutritional supplement enriched with vitamin B6, containing $57.73 \%$ protein and vitamin B6 $2,85 \mathrm{mg}$ of was obtained. Which contributes between $17,319 \mathrm{~g}-28,865 \mathrm{~g}$ protein per $30 \mathrm{~g} 50 \mathrm{~g}$ lyophilized. Based on the results it is concluded that the food product is rich in protein, with an amino acid profile within the parameters required by the FAO and microbiologically safe.
\end{abstract}

Keyword- Functional food, High performance, Energy drink, Nutritional supplement.

\section{INTRODUCTION}

The formulation of mixtures of cereals and legumes, allows to obtain an improvement in the amino acid balance, which translates into a superior value in the quality of the protein compared to each one separately, because legumes are a better source of lysine than cereals and these represent a higher source of sulfur amino acids $[1,2,3]$.

Soy is a product of high biological value that has gained recognition by the consumer for the association made to health benefits [4], this has generated a growing market for food products with soy protein, which is currently produced in large volumes: 155 million metric tons of soybeans are cultivated worldwide, of which $38 \%$ are in the United States, followed by Brazil (25\%), Argentina (19\%), China (7\%), India (3\%), Canada (2\%), and Paraguay (2\%), while the rest of the countries cultivated only about $4 \%$, on an average of $40 \%$ protein contained in soybeans, 63.6 million metric tons of soy protein per year, available for consumption [5].

Likewise, due to its high agricultural and nutritional potential, interest in quinoa has increased in the last years, until it became a diversification alternative for the Andean region [6]. At present it is considered a product "star" in the world for its nutritional and medicinal properties. It presents different varieties of species, and it is the only one among the cereals that owns all the amino acids, besides being the unique alternative between the foods of vegetal origin to replace the animal protein. In this sense, to a large extent, the increase in its production and export is attributable to such qualities [7,8].

Within all the applications that have at the food level are the drinks with soy protein, which may be neutral, such as the so-called soy milk that are the most current consumption [9] and acidic, which correspond to mixtures with juices of fruit [10]. Quinoa within the Andean grains is the most versatile for consumption. Whole grain, raw or toasted flour, flakes, semolina and instant powder can be prepared in multiple ways [11,12]. The objective of this work was to obtain a protein nutritional supplement using soy and quinoa grains, enriched with vitamin B6, intended for people with high physical performance. 


\section{MATERials AND Methods}

\section{Physical Determination and Proximal Chemical Composition}

The physicochemical determinations are the tests that refer to the bromatological characteristics, were made by estimation of the proximal composition through finely ground samples. The methods used for physicochemical characteristics are shown in Table 1.

Table I. Methodology for physico-chemical analysis

\begin{tabular}{|c|c|}
\hline Parameter & Method \\
\hline Humidity & AOAC 925.10 \\
\hline Protein & AOAC 920.87 \\
\hline Total Carbohydrates or Carbohydrates & AOAC 995.13 \\
\hline Grease & AOAC 920.39 \\
\hline Ashes & AOAC 923.03 \\
\hline
\end{tabular}

\section{Obtaining the flour}

To ensure a fine and homogeneous material, two grinds were made to the grain samples, an initial one in order to achieve a low tegument flour. In addition, a second to get smaller particles. Both grinding products will be sifted; the soybeans will be partially defatted.

\section{Protein Extraction Method}

The method for the extraction of proteins was done by wet method, the flour obtained from soybean and quinoa was obtained, then the flour with a higher protein content was chosen and flour-water suspensions were prepared in ratios of $1: 6,1: 7: 1: 8: 1: 9,1: 10$. The mixture is heated at $40^{\circ} \mathrm{C}$ for $40 \mathrm{~min}$. With constant stirring and adjusting the $\mathrm{pH}$ of the medium to 7 using $1 \mathrm{~N} \mathrm{NaOH}$, then let stand and decant. The supernatant is removed and the amylaceous residue obtained in the bottom is washed twice with water under the same conditions of time and temperature, with stirring to solubilize the protein of the mixture, adjusting $\mathrm{pH}$, centrifuging for a determined time and decanting to obtain the proteins and starch residues. Finally, the protein extract and the supernatants are deposited in the same container [13].

\section{Obtaining the final formulation of the beverage}

Having obtained the results of the sensory analysis, the ideal formulation for the final beverage is chosen, based on those parameters that influence the evaluated characteristics, as for example for its color the most relevant parameter is the addition of dye, therefore the amount of this is the one that gives us the characteristic of intensity and tone.

\section{Initial Characterization}

\section{III.RESULTS AND DISCUSSION}

The bromatological analyzes show that soy has a much higher protein content than that of quinoa, and these are found in $30.255 \%$ and $19.90 \%$ of protein, comparing with some other vegetable products we are aware that they are highly protein rich products and which complement each other perfectly. For the extraction of the flours, equal weights were used, taking $8000 \mathrm{~g}$ of soybean and quinoa, from which was obtained $6175 \mathrm{~g}$ of Integral soybean meal and $6900 \mathrm{~g}$ of integral quinoa flour, this being a yield of $77.18 \%$ and $86.26 \%$ respectively.

Table 2 shows the evaluation of the flour sample preparation process, the flour combination with the highest protein content was the formula $70 / 30$, with a protein content of $28.59 \%$, as measured that the content of soybeans increased as protein content increased, we can infer that soybeans by containing a higher percentage of protein is the element that contributes more of this nutritional component.

Table II. Nutritional comparison of soybean, quinoa and flour S / Q 70/30

\begin{tabular}{|c|c|c|c|c|}
\hline Parameters & Unit & Soybean & Quinoa & Flour 70/30 \\
\hline Protein & $(\%)$ & 30,255 & 14,900 & 28,590 \\
\hline Grease & $(\%)$ & 23,920 & 5,780 & 18,480 \\
\hline Humidity & $(\%)$ & 7,600 & 10,820 & 8,560 \\
\hline Carbohydrates & $(\%)$ & 28,890 & 59,720 & 35,210 \\
\hline Ashes & $(\%)$ & 5,350 & 2,545 & 4,500 \\
\hline Raw Fiber & $(\%)$ & 3,985 & 6,235 & 4,660 \\
\hline
\end{tabular}




\section{Evaluation of chemical analysis of protein concentrate}

After lyophilizing the protein clot, a concentrated product was obtained with $9.5 \%$ moisture, 65.85\% protein and $24.8 \%$ total solids. The weight of the concentrate obtained was $70 \mathrm{~g}$ and starting from $100 \mathrm{~g}$ of S / Q flour mixture, with three dilutions of which a protein extract of $2500 \mathrm{ml}$ was obtained, which provided $1500 \mathrm{ml}$ of protein coagulum. With a yield of $70 \%$ based on the flour mixture S / Q and of $2.8 \%$ and $4.66 \%$ in relation to the protein extract and the protein clot respectively.

\section{Evaluation of SNPEB6 lyophilization}

$45.6 \mathrm{~g}$ of lyophilizate were obtained, starting from $200 \mathrm{~g}$ of the mixture, indicating a yield of $22.8 \%$, the protein content is in the range of $57.73 \%$ which gives us $26.32 \mathrm{~g}$. The tests made for reconstitution after being evaluated sensorially, show that 30 grams to 40 grams of lyophilized must be used for $170 \mathrm{~mL}-160 \mathrm{~mL}$ of water, providing this mixture an amount of protein between $17.32 \mathrm{~g}-23.10 \mathrm{~g}$ per dilution. It is possible to make a dilution with a larger amount of lyophilizate, such as $50 \mathrm{~g}$ of lyophilized per $150 \mathrm{~mL}$ of water, although this provides us with a higher protein content of $28.87 \mathrm{~g}$, its characteristics were not well accepted by the panel.

Although the protein content of the final product does not meet the recommendations of the FAO / WHO / UN, Colombian Institute of Family Welfare (ICBF) and the GDR, which range from $40 \mathrm{~g}$ to $60 \mathrm{~g}$ daily protein for a healthy adult, however it provides about $50 \%$ of the requirement, leaving the other $50 \%$ to the daily diet, thus becoming a product of excellent protein source and nutritional quality. The amino acid profile of the nutritional supplement is above the essential amino acid requirements of the ideal proteins as shown in Table 2, thus meeting the body's needs during its intake.

Table III. Comparison of essential amino acid requirements of the ideal proteins with the amino acid profile of the protein nutritional supplement

\begin{tabular}{|c|c|c|c|c|c|}
\hline Aminoacids & $\begin{array}{l}\text { Young children (0 } \\
\text { - } 6 \text { months) needs } \\
\text { (mg/día/Kg) }\end{array}$ & $\begin{array}{c}\text { Children (10 - } 12 \\
\text { years) Needs } \\
\text { (mg/día/Kg) }\end{array}$ & $\begin{array}{c}\text { Adults Needs } \\
\text { (mg/día/Kg) }\end{array}$ & $\begin{array}{c}\text { Ideal } \\
\text { composition } \\
(\mathrm{mg} / \mathrm{Kg})\end{array}$ & $\begin{array}{c}\text { Freeze-dried } \\
\text { composition } \\
(\mathrm{mg} / \mathrm{Kg})\end{array}$ \\
\hline Histidine & 28 & 0 & 0 & 0 & 74,6 \\
\hline Isoleucine & 70 & 30 & 10 & 18 & 41,15 \\
\hline Leucine & 161 & 45 & 14 & 25 & 379,9 \\
\hline Lysine & 103 & 60 & 12 & 22 & 47,30 \\
\hline $\begin{array}{l}\text { Methionine (+ } \\
\text { cysteine) a }\end{array}$ & 58 & 27 & 13 & 24 & 42,20 \\
\hline $\begin{array}{l}\text { Phenylalanine (+ } \\
\text { tyrosine) b }\end{array}$ & 125 & 27 & 14 & 25 & 87,85 \\
\hline Threonine & 87 & 35 & 7 & 13 & 58,70 \\
\hline Tryptophan & 17 & 4 & 3,5 & 6,5 & 61,40 \\
\hline Valine & 93 & 33 & 10 & 18 & 34,50 \\
\hline $\begin{array}{l}\text { Total Essential } \\
\text { Amino Acids }\end{array}$ & 742 & 261 & 83,50 & 151,50 & 827,60 \\
\hline
\end{tabular}

a Cysteine can provide up to one-third of the total needs for sulfur amino acids

b Tyrosine can contribute up to one-third of the total aromatic amino acid requirement

If we compare the amino acid content of soybeans with FAO standards we can observe that the product obtained has the characteristics of a good supplement because its content conforms to the FAO standard. We also see that it exceeds soybeans as shown in Table 3 in comparison to its limiting amino acid content, which is methionine + cysteine, with the latter being $42.2 \mathrm{mg} / \mathrm{kg}$ and soybeans $28 \mathrm{mg} / \mathrm{kg}$, as with cow's milk, and wheat. 
Table IV. Comparative content of essential amino acids and nutritive value of soybean, quinoa and SNPEB6 protein in relation to the FAO standard

\begin{tabular}{|c|c|c|c|c|c|c|c|c|}
\hline Parameters & $\begin{array}{c}\text { Cow } \\
\text { milk }\end{array}$ & $\begin{array}{c}\text { Chicken } \\
\text { egg }\end{array}$ & $\begin{array}{c}\text { Meat } \\
\text { (beef) }\end{array}$ & Wheat & $\begin{array}{c}\text { Grain } \\
\text { Soybeans }\end{array}$ & $\begin{array}{c}\text { Quinoa } \\
\text { beans }\end{array}$ & Supplement & FAO \\
\hline Histidine & 27 & 22 & 34 & 25 & 28 & 27 & 74,60 & 0 \\
\hline Isoleucine & 47 & 54 & 48 & 35 & 50 & 64 & 41,15 & 40 \\
\hline Leucine & 95 & 86 & 81 & 72 & 85 & 71 & 379,9 & 70 \\
\hline Lysine & 78 & 70 & 89 & $31^{\text {a }}$ & 70 & 66 & 47,30 & 55 \\
\hline $\begin{array}{c}\text { Methionine + } \\
\text { cysteine }\end{array}$ & $33^{\mathrm{a}}$ & 57 & 40 & 43 & $28^{\text {a }}$ & 45 & 62,20 & 35 \\
\hline $\begin{array}{c}\text { Phenylalanine + } \\
\text { Tyrosine }\end{array}$ & 102 & 93 & 80 & 80 & 88 & 74 & 87,85 & 60 \\
\hline Threonine & 44 & 47 & 46 & 31 & 42 & 48 & 58,70 & 40 \\
\hline Tryptophan & 14 & 17 & 11 & 12 & 14 & 11 & 61,40 & 10 \\
\hline $\begin{array}{c}\text { Valine } \\
64\end{array}$ & 66 & 50 & 47 & 53 & 50 & 34,50 & 50 \\
\hline $\begin{array}{c}\text { Total essential } \\
\text { amino acids, } \\
\text { without histidine }\end{array}$ & 477 & 490 & 445 & 351 & 430 & 429 & 773 & 360 \\
\hline
\end{tabular}

a Limiting amino acid in the diet

The amount of vitamin B6 in the protein nutritional supplement is at a rate of 2.85mg, well above the requirement, since the supplement contains between 17 - 23g of protein and the calculation for this amount is $0.345 \mathrm{mg}$. According to the ICBF and the GDR, the vitamin content supplies the daily needs of the different groups of consumers, finding that for these the recommendations are: for infants $0.6 \mathrm{mg} /$ day, children 3mg / day, adolescents $1.9 \mathrm{mg} /$ day , adults $2.1 \mathrm{mg} /$ day and women in pregnancy and / or lactation, $2.6 \mathrm{mg} / \mathrm{day}$. Being that the nutritional supplement protein has a content of $2.85 \mathrm{mg} / \mathrm{kg}$.

\section{IV.CONCLUSIONS}

From the results obtained, the following conclusions can be presented: 1) A protein-rich food product was obtained, with an amino acid profile within the parameters required by the FAO and microbiologically safe; 2) The bromatology tests show that it is a product rich in nutrients, which does not render irrelevant its other components in the strict sense that is not a purely protein product but also contains other nutritional characteristics; 3) The vitamin B6 content makes it a product that ensures its assimilation, as it is within the established, which should be on average $13 \mathrm{mg} / \mathrm{kg}$ of protein and the reference intakes are based on $15 \mathrm{mg} / \mathrm{kg}$ of protein.

\section{REFERENCES}

[1] J. Jaimes, I. Rios and C. Severiche, Nanotechnology and its applications in the food industry, Revista Alimentos Hoy, 25, (2017), 5176.

[2] J. Jaimes, A. Acosta, C. Severiche, Y. Marrugo and E. Bedoya, Evaluation of the Functional Properties of Prosopis juliflora Protein Concentrate Obtained by Different Methods, International Journal Of Engineering And Technology, 9, (2017), 3841-3847

[3] I. Baldiris, Y. Marrugo, C. Severiche, J. Jaimes, W. Fong, L. Vargas, E. Bedoya and H. Cohen, Delayed Organoleptic Maturation of Tomato Variety Milano (Lycopersicum esculentum Mill) Using Giberelina, International Journal of ChemTech Research, 10, (2017), 1032-1037.

[4] A. Ebert, C. Chang, M. Yan and R. Yang, Nutritional composition of mungbean and soybean sprouts compared to their adult growth stage, Food Chemistry, 237, (2017), 15-22.

[5] A. Teixeira, L. Ribeiro, S. Rezende, E. Barros and M. Moreira, Development of a method to quantify sucrose in soybean grains, Food Chemistry, 130, (2012), 1134-1136.

[6] S. Navruz and N. Sanlier, Nutritional and health benefits of quinoa (Chenopodium quinoa Willd.), Journal of Cereal Science, 69, (2016), 371-376.

[7] F. Huaman, E. Toscano, O. Acosta, D. Rojas, M. Inocente, D. Garrido and M. Guevara, Estudio genotóxico de una bebida experimental de quinua, kiwicha y kañiwa, Revista Peruana de Biología, 21, (2014), 251-258.

[8] G. De Santis, C. Maddaluno, T. D’Ambrosio, A. Rascio, M. Rinaldi and J. Troisi, Characterisation of quinoa (Chenopodium quinoa Willd.) accessions for the saponin content in Mediterranean environment, Italian Journal Of Agronomy, 11, (2016), $277-281$.

[9] M. Grace, C. Danao, R. Zandonadi and R. Gates, Development of a grain monitoring probe to measure temperature, relative humidity, carbon dioxide levels and logistical information during handling and transportation of soybeans, Computers and Electronics in Agriculture, 119, (2015), 74-82.

[10] P. Cerezal, E. Acosta, G. Rojas, N. Romero and R. Arcos, Desarrollo de una bebida de alto contenido proteico a partir de algarrobo, lupino y quinoa para la dieta de preescolares, Nutrición Hospitalaria, 27, (2012), 232-243. Ç 
[11] V. Nowak, J. Du and R. Charrondière, Assessment of the nutritional composition of quinoa (Chenopodium quinoa Willd.), Food Chemistry, 193, (2016), 47-54.

[12] Y. Marrugo, C. Vargas, C. Severiche, J. Jaimes and E. Bedoya, Evaluation of the Functional Properties of Bean Starch Zaragoza (Phaseolus lunatus) White Variety in a Food Type Sausage, International Journal Of Engineering And Technology, 9, (2017), 3674 3679 .

[13] Y. Marrugo, C. Severiche and J. Jaimes, Development of a Food Product Type Based Sauce Egg plant (Solanum melongena), International Journal of ChemTech Research, 10, (2017), 567-571. 